\title{
DEPOSITARY FUNCTION OF PSEUDOMONAS AERUGINOSA BIOFILM ON MEDIA WITH DIFFERENT CARBON SOURCE CONCENTRATIONS
}

\author{
O.I. Balko, L.V. Avdeeva, O.B. Balko \\ Zabolotny Institute of Microbiology and Virology, NAS of Ukraine, \\ 154 Acad. Zabolotny Str., Kyiv, 03143, Ukraine \\ e-mail:olga-balko@ukr.net
}

\begin{abstract}
The aim of work was study of peculiarities of Pseudomonas aeruginosa biofilm formation on media with different concentration of glucose as sole source of carbon and energy. Methods. Three Pseudomonas aeruginosa strains were cultivated in stationary system on glass in Kozer medium with $0.1 \%, 5 \%$ and $20 \%$ of glucose. The effect of unfavourable conditions on microorganism growth was analyzed by intensity of biofilm formation and quantities of viable cells in biofilm and planktonic form. Results. It was determined that investigated cultures maintained the ability to grow and form biofilm in the presence of 0.1-20\% glucose in Kozer medium. If there was $0.1 \%$ of glucose, dynamics of biofilm accumulation was characterized by strain peculiarities. But under increase of carbon source concentration to $20 \%$, these differences became less evident and biofilm formation acquired common for all used cultures regularities. The increase of glucose concentration caused reduction of the sample area covered by biofilm and fall of microorganism quantity in its composition, stabilized the biofilm formation dynamics, but didn't influence on bacterium titre in planktonic form. Conclusions. Under the influence of unfavourable conditions, besides protective function, Pseudomonas aeruginosa biofilm can perform the role of depositary formation, maintaining stable cell quantity in planktonic form.
\end{abstract}

Keywords: Pseudomonas aeruginosa, biofilm formation, microorganisms in planktonic and biofilm form, carbon source concentration.

In nature microorganisms always undergo unfavourable conditions of environment. Concentration of carbon source in culture medium is one of the basic factors, influencing on microorganism growth [1]. Not only minimum, but maximum measures of this parameter play an important role, since redundant concentration of any medium component is able to influence on the growth of planktonic form microorganism and their biofilm formation [2]. In the end of the 21 century it was shown that in the environment conditions microorganisms predominately exist in an attached state in a biofilm composition [3]. It was shown that the expression of some cell genes, which are inactive in planktonic form, occur in biofilm composition [4]. As a result the properties of microorganisms in planktonic form substantially differ from analogous ones in biofilm [5]. In addition the formation of such bacterial community optimizes functions of microorganisms, improves cell to cell communication, and also increases the resistance to unfavorable factors of environment, thus providing collective existence advantages [6]. Pseudomonas aeruginosa is one of main modeling means for the study of microorganism functional regularities in biofilm composition [7]. Often the results obtained with this modelling technique 
are extrapolated to related microorganisms [8]. In our previous investigations it was noted that the biofilm of Pseudomonas aeruginosa strains can perform not only protective function, but some other uninvestigated properties [9]. To research this function of biofilm we have modeled the unfavorable environmental conditions using different quantities of carbon source. Changing quantity of glucose as soul source of carbon and energy we exposed Pseudomonas aeruginosa strains to directed stress factor. It is necessary to emphasize, that in spite of significant achievements in biofilm investigation, nutritional conditions, such as carbon source concentrations, still influence on results of the biofilm formation studies, even finding universal antibiofilm compounds [10].

Thus, the aim of our work was study of characteristics of Pseudomonas aeruginosa biofilm formation under unfavourable conditions on the model of cultivation in media with different amounts of glucose as sole carbon source.

Materials and methods. The influence of unfavourable conditions on biofilm formation was studied using three collection strains: Pseudomonas aeruginosa: UCM B-1 (ATCC 10145), UCM B-12 (CCM 1500) and UCM B-900 (ATCC 9027) - kept in Ukrainian collection of microorganisms (UCM, Zabolotny Institute of Microbiology and Virology, National Academy of Sciences of Ukraine). These cultures were grown in synthetic Kozer medium having minimal salt composition which is needed for growth of Pseudomonas strains [11]. Glucose was added up to a final concentration $-0.1 \%, 5 \%$ and $20 \%$ (w/v in Kozer medium) as the sole carbon source. Cultivation of microorganism was conducted in a stationary system [12].

For this, covered glasses $18 \times 18 \mathrm{~mm}, 1.8 \mathrm{ml}$ of Kozer medium with proper concentration of glucose and $0.2 \mathrm{ml}$ of tenfold dilution of twenty-four-hour culture of researched $P$. aeruginosa strain (final titre $2 \times 10^{7} \mathrm{CFU} \mathrm{ml}^{-1}$ ) were added to culture vessels $(30 \times 50 \mathrm{~mm}, 20 \mathrm{ml}$ volume $)$. A double number of culture vessels was used in the experiment, taking into account the planned sampling frequency. The cultivation was conducted at $37^{\circ} \mathrm{C}$ for 7 days. Every day two vessels were taken away for measuring of biofilm intensity [13] and $P$. aeruginosa cell quantities in biofilm and planktonic form [14].

A number of mean values were determined to assist with the study of common dependence regularities. Note this applies to all studied parameters for the cell amounts in biofilm and planktonic form for all studied strains in different glucose concentrations. Here are the definitions:

$\mathrm{NP}_{\mathrm{av}}$ - the average quantity of viable cells in planktonic form during the observation period. This parameter was calculated by dividing the sum of freeswimming bacteria titers by number of all tested samples.

$$
\mathrm{NPl}_{\mathrm{av}}=\left(\mathrm{N}_{1 \text { day }}+\mathrm{N}_{2 \text { day }}+\ldots \mathrm{N}_{7 \text { day }}\right) / \mathrm{T} \text {, }
$$

where $\mathrm{N}_{1 \text { day }}$ - quantity of viable cells in planktonic form on the first observation day, etc; $\mathrm{T}$ - quantity of observation days.

$\mathrm{NBp}_{\mathrm{av}}$ - the average quantity of viable cells in biofilm composition over the observation period. This parameter was determined in the same manner as $\mathrm{NPl}_{\mathrm{av}}$.

$$
\mathrm{NBp}_{\mathrm{av}}=\left(\mathrm{N}_{1 \text { day }}+\mathrm{N}_{2 \text { day }}+\ldots \mathrm{N}_{7 \text { day }}\right) / \mathrm{T} \text {, }
$$

where $\mathrm{N}_{1 \text { day }}$ - quantity of viable cells in biofilm composition on the first observation day, etc; $\mathrm{T}$ - quantity of observation days. 
$\mathrm{B}_{\mathrm{av}}$ - the average sample area covered by biofilm during the observation period. This parameter was determined in the same manner as $\mathrm{NPl}_{\mathrm{av}}$.

$$
\mathrm{B}_{\mathrm{av}}=\left(\mathrm{B}_{1 \text { day }}+\mathrm{B}_{2 \text { day }}+\ldots \mathrm{B}_{7 \text { day }}\right) / \mathrm{T} \text {, }
$$

where $\mathrm{B}_{1 \text { day }}$ - area covered by biofilm on the first observation day, etc; $\mathrm{T}$ quantity of observation days.

$\mathrm{NBp}_{\mathrm{sp}}$ - the average exponent of specific quantity of viable cells in biofilm form in relation to the sample area covered by biofilm during the observation period. This parameter was calculated by dividing $\mathrm{NBp}_{\mathrm{av}}$ by $\mathrm{B}_{\mathrm{av}}$.

$$
\mathrm{NBp}_{\mathrm{sp}}=\mathrm{NBp}_{\mathrm{av}} / \mathrm{B}_{\mathrm{av}}
$$

$\mathrm{B}_{\max }$ - the index of maximum biofilm formation during the observation period. This index is equal to maximal value of sample area covered by biofilm (B) among all sample test values determined for this strain during the observation period.

$$
\mathrm{B}_{\max }=\operatorname{MAX}\left(\mathrm{B}_{1 \text { day }}, \mathrm{B}_{2 \text { day }} \ldots \mathrm{B}_{7 \text { day }}\right)
$$

$\mathrm{B}_{\mathrm{amp}}$ - the fluctuation amplitude of sample area covered by biofilm during the observation period. This index is equal to subtraction of maximum and minimum of the measured sample area covered by biofilm (B) during the observation period.

$$
\mathrm{B}_{\text {amp }}=\mathrm{B}_{\max }-\mathrm{B}_{\min }
$$

where $\mathrm{B}_{\min }$ - the index of minimum biofilm formation during the observation period. $\mathrm{B}_{\min }=\mathrm{MIN}\left(\mathrm{B}_{1_{\text {day }}}, \mathrm{B}_{2 \text { day }} \ldots \mathrm{B}_{7 \text { day }}\right)$.

Results. During the cultivation of $P$. aeruginosa UCM B-900 in Kozer medium with $0.1 \%$ glucose the stepped percentage increase of sample area covered by biofilm was documented. The index peak (of $54 \mathrm{~mm}^{2}$ ) was reached on day 4 (Fig. 1a).

On subsequent days (5-7), it was observed that the decrease in this characteristic was in a stepped manner. On the 1 st day, an increase was seen in the quantity of viable cells in biofilm composition (reaching $1.4 \times 10^{6}$ CFU $\mathrm{ml}^{-1}$ ). Then from the $2^{\text {nd }}$ to the $7^{\text {th }}$ day, this index remained in dynamic balance over the range $2.1 \times 10^{5}$ to $3.0 \times 10^{6} \mathrm{CFU} \mathrm{ml^{-1 }}$. The titre of microorganisms in planktonic form was characterized by more stable values. During the observation period, this stable value parameter ranged from $1.3 \times 10^{7}$ to $5.2 \times 10^{7}$ CFU ml ${ }^{-1}$. Other researched cultures $P$. aeruginosa - UCM B-1 and UCM B-12 differed more intensively in the amount of biofilm formation (Fig. 1b, c). So, comparing with UCM B-900, the maximum sample areas covered by biofilm was up by $14 \%$ for UCM B-1 and up by $38 \%$ for UCM B-12.

The biofilm formation of $P$. aeruginosa UCM B-1 was characterized by twopeak type. The reason for such phenomenon could be the early achievement of first maximal accumulation on the $2^{\text {nd }}$ day. The variation dynamics of cell quantity in biofilm and planktonic form for strains UCM B-1 UCM B-12 were in comparable with UCM B-900 characteristics. Thus, despite the minimal amount of glucose all researched strains were able to grow and to form biofilm. It was interesting that bacterial titres of different strains on the certain time points were not the same. The possible reason of such phenomenon may be due to the different source of their isolation [9]. 

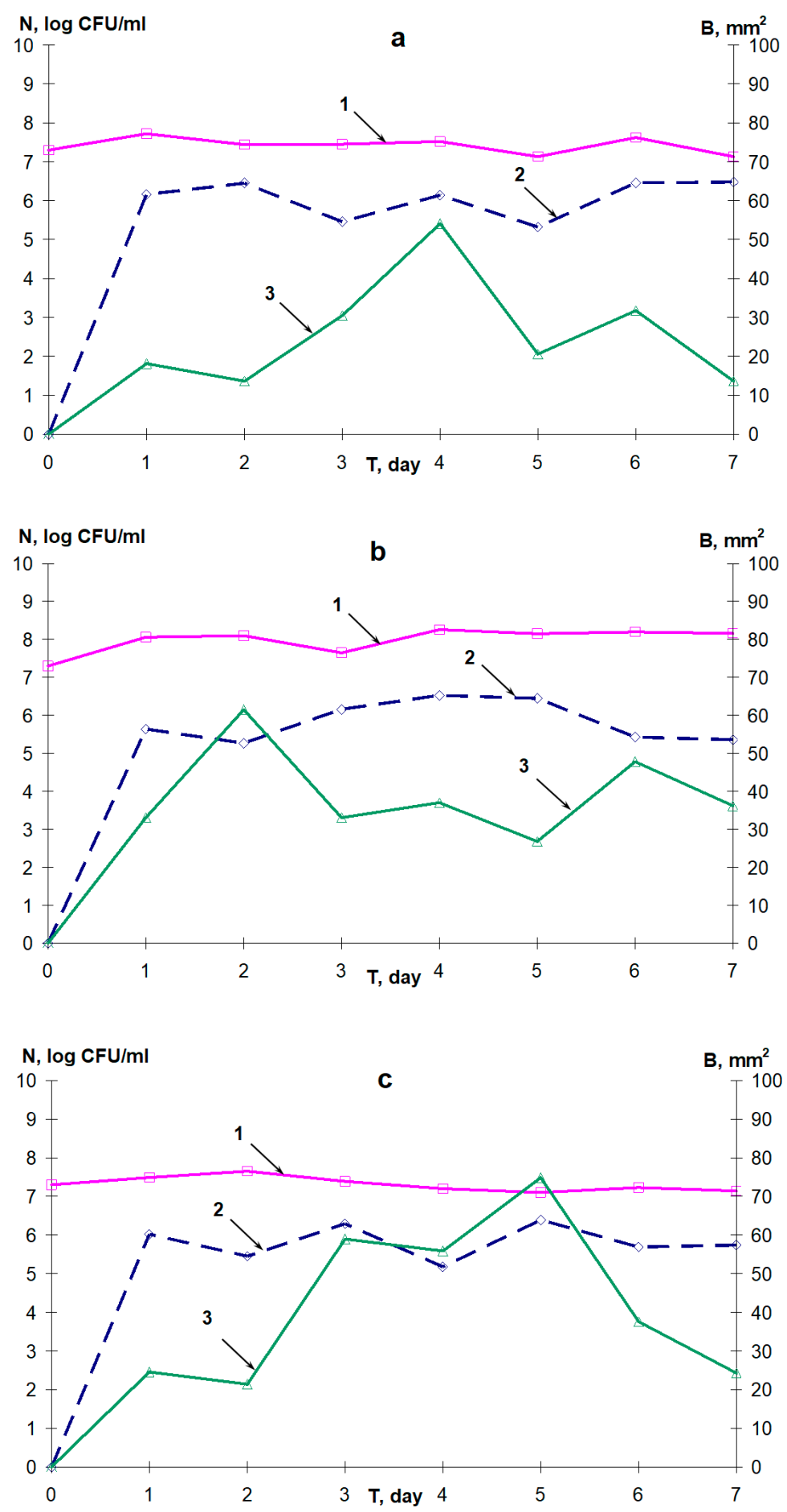

Fig. 1. The process of biofilm formation by collection strains Pseudomonas aeruginosa UCM B-900 (a), UCM B-1 (b) and UCM B-12 (c) in minimal Kozer medium with $0,1 \%$ of glucose

There and in Fig 2-3: N - quantity of viable cells: in planktonic form $(1,-\square-)$, in biofilm composition $(2,--\diamond--)$. B - sample area covered by biofilm $(3,-\Delta-)$; $\mathrm{T}-$ time of observation. 
During the cultivation of $P$. aeruginosa UCM B-900 in Kozer medium with $5 \%$ of glucose the temperate biofilm formation, an absence of sharp fluctuations was observed (Fig. 2a). It should be noted that the maximal sample area covered by biofilm and the fluctuation amplitude of this parameter during the observation period in the medium with $0.1 \%$ of glucose changed from 54.1 and $40.5 \mathrm{~mm}^{2}$. Whereas, the addition of $5 \%$ of glucose caused the decrease of these characteristics from 37.3 to $20.4 \mathrm{~mm}^{2}$. In a Kozer medium with $5 \%$ of glucose, the sample area covered by biofilm increased gradually and reached $32 \mathrm{~mm}^{2}$ by the $3^{\text {rd }}$ day of observation. Then a slow decrease of formed biofilm area to $21 \mathrm{~mm}^{2}$ was observed at 5th day with its repeated accumulation to $37 \mathrm{~mm}^{2}$ at 7th day of observation.

Simultaneously the quantity of microorganisms in biofilm form was subjected to essential changes over the range $1 \times 10^{4}$ to $3.6 \times 10^{7} \mathrm{CFU} \mathrm{ml}{ }^{-1}$. The analogous regularity was observed in the quantity of microorganisms in planktonic form.

Thus, the initial growth of microorganism titre to $7.8 \times 10^{8} \mathrm{CFU} \mathrm{ml}^{-1}$ during first 2 days was replaced by gradual decrease of microorganism quantity to $1.3 \times 10^{7} \mathrm{CFU} \mathrm{ml^{-1 }}$ at $4^{\text {th }}$ day. At a later period a similar cyclicism was seen, but at a lower intensity of variation. During growth of other researched $P$. aeruginosa strains on this medium it was observed the two-stage biofilm accumulation, which was pronounced too much for UCM B-1 (Fig. 2b, c). These cultures had essential fluctuations in cell quantity in biofilm and planktonic forms. The mentioned results for UCM B-1 were over the range $1 \times 10^{4}$ to $1.6 \times 10^{6}$ and $2 \times 10^{7}-1.4 \times 10^{9} \mathrm{CFU} \mathrm{ml}^{-1}$, for UCM B-12 $-3.5 \times 10^{3}-4.7 \times 10^{6}$ and $1 \times 10^{7}-1.2 \times 10^{9} \mathrm{CFU} \mathrm{ml}^{-1}$, respectively.

During the cultivation of $P$. aeruginosa UCM B-900 in Kozer medium with $20 \%$ of glucose the low intensity of biofilm formation was observed. The sample area covered by biofilm increased gradually and at the 3rd day reached maximum results $-18.8 \mathrm{~mm}^{2}$ (Fig. 3a). A tendency for a stepped decrease of this index to $6.5 \mathrm{~mm}^{2}$ at the 7th day of cultivation was also observed. In biofilm composition the microorganism (total) quantity reached its maximum on the 2nd day and was equal to $9.8 \times 10^{4} \mathrm{CFU} \mathrm{ml^{-1 }}$. Subsequently their titre decreased gradually and attained $5.0 \times 10^{3} \mathrm{CFU} \mathrm{ml}^{-1}$ at the final stage of observation. The microorganisms in planktonic form during all experiments were maintained at a stable high level - at an average $5.4 \times 10^{7} \mathrm{CFU} \mathrm{ml}{ }^{-1}$ with minimal deflection.

Thus, examined $P$. aeruginosa strains maintained the ability to grow even under the presence of $20 \%$ of glucose in the medium - under strong osmotic pressure for the cells. It was noted, that with increased carbon source concentration, strain differences diminished partially and biofilm formation dynamics of their biofilm formation became more identical. So, the cultivation in the Kozer medium with $0.1 \%$ of glucose caused the intensive changes in sample area covered by biofilm, which was observed for different strains at different periods of time. The increasing of glucose concentration up to $5 \%$ resulted in considerable decrease of biofilm area and diminution of fluctuation amplitude of biofilm formation indexes, whereas in the medium with $20 \%$ of glucose all strains used were characterized by low intensity of biofilm formation. It could be noted, that in media with $0.1 \%, 5 \%$ and $20 \%$ of glucose maximum sample area covered by biofilm of UCM B-900 strain was equivalent to a biofilm area of 54.1, 37.3 and $18.8 \mathrm{~mm}^{2}$, respectively. 

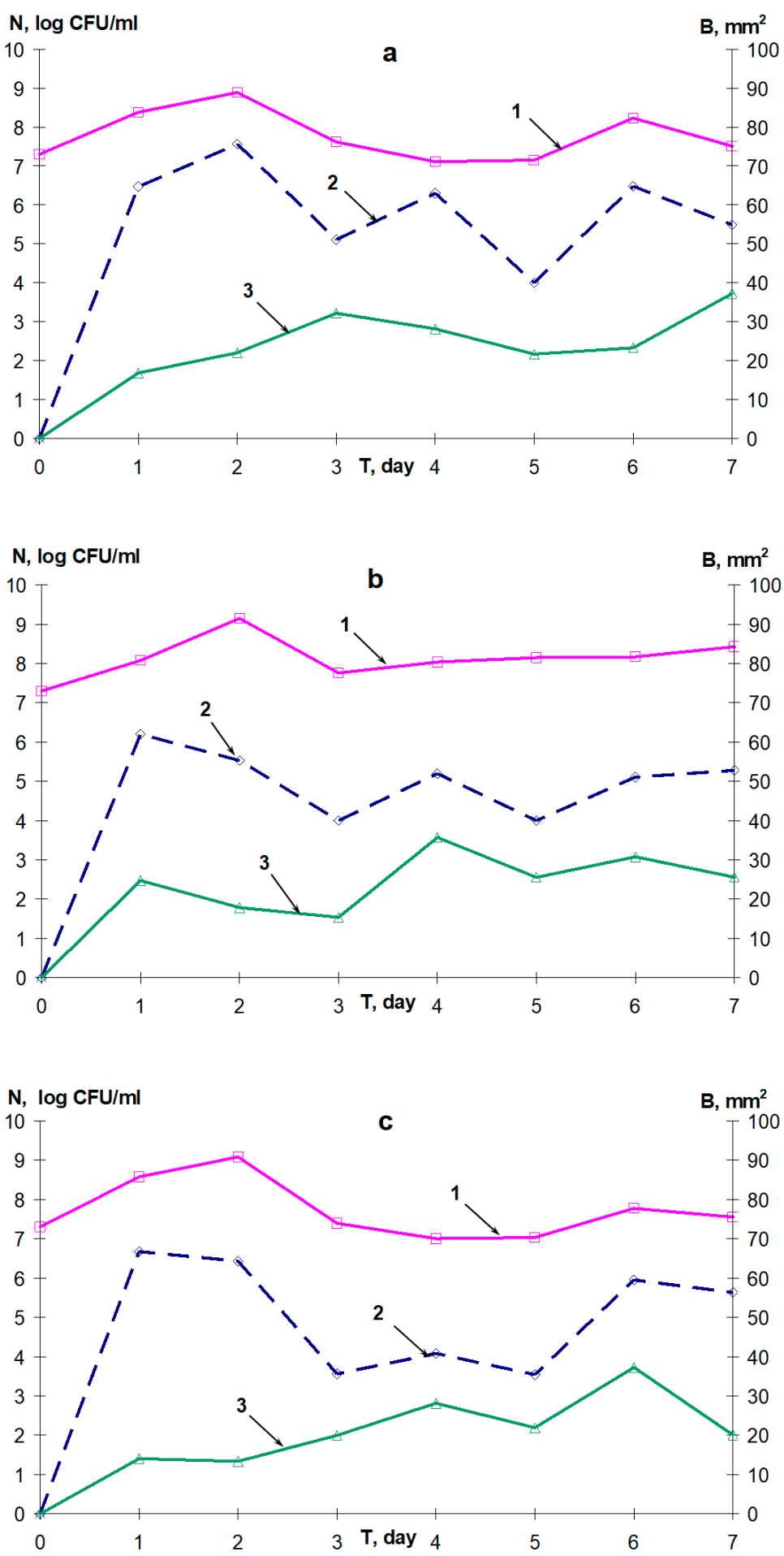

Fig. 2. The process of biofilm formation by collection strains Pseudomonas aeruginosa UCM B-900 (a), UCM B-1 (b) and UCM B-12 (c) in minimal Kozer medium with $5 \%$ of glucose 

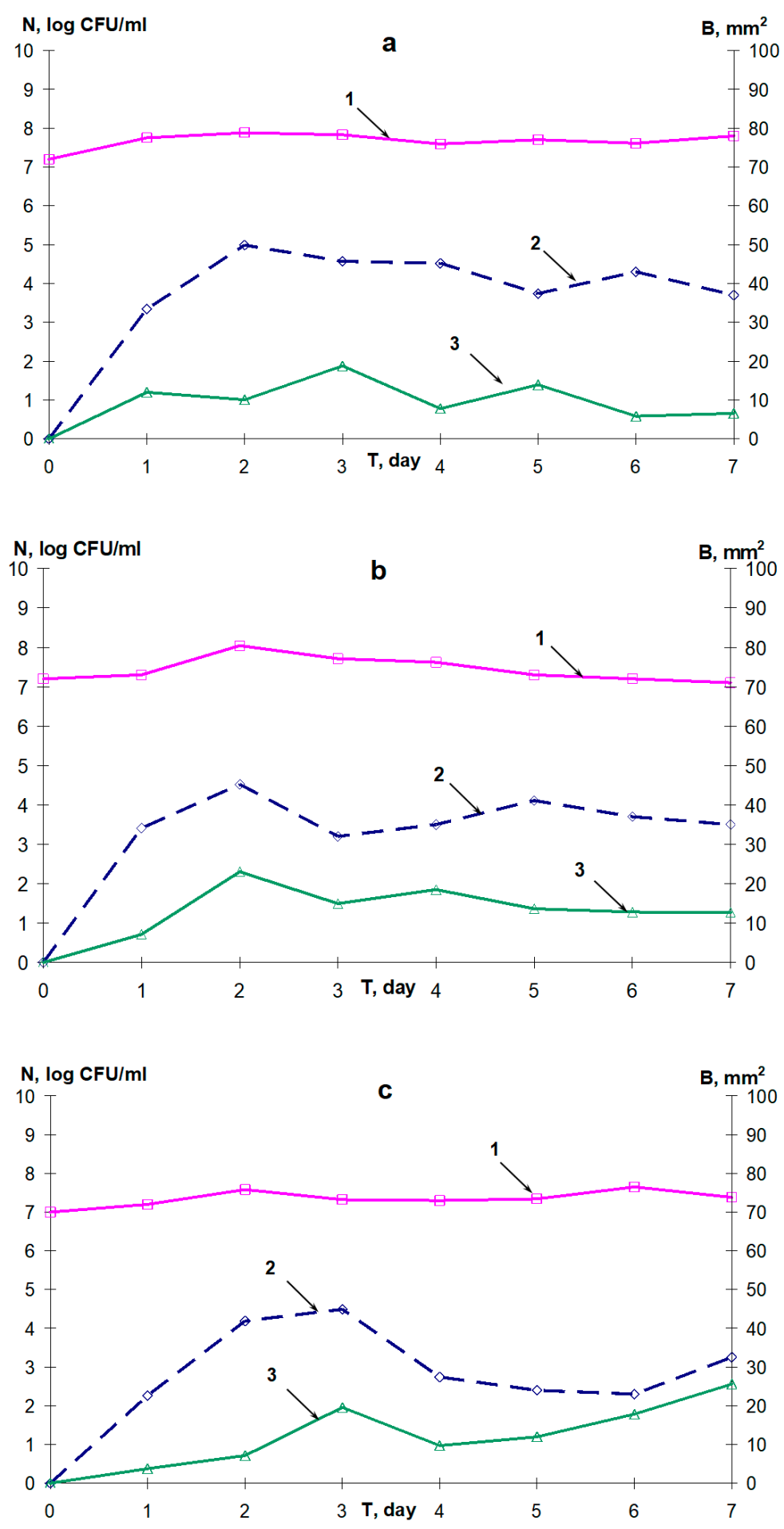

Fig. 3. The process of biofilm formation by collection strains Pseudomonas aeruginosa UCM B-900 (a), UCM B-1 (b) and UCM B-12 (c) in minimal Kozer medium with $20 \%$ of glucose 
The dynamics of biofilm formation by UCM B-1 and UCM B-12 strains (Fig. 3b, c) approximated to P. aeruginosa UCM B-900 characteristics. Thus, it was revealed the difference unification, which included the reduction of sample area covered by biofilm, the lessening of its variation during all observation period, and stabilization of cell quantity in planktonic form. Probably, under high intensity of unfavourable environmental conditions, this impacted different microorganisms exhibit more common characteristics of biofilm formation type.

Though, regardless of concentration of glucose added in cultivation medium, all strains kept their behaviour of biofim formation. For UCM B-1 the most intensive sample covering by biofilm was observed at first stages of observation (1-2 days), whereas UCM B-12 was characterized by maximum indexes later on (5-7 days). The peak indexes of biofilm accumulation for UCM B-900 occupied in an intermediate period on days 3 to 4 .

Comparison of different indexes for growth of three strains in media with different concentrations of carbon source was complicated by large quantity of data processed. To simplify the analysis of results and improve factors for quantitative assessment of biofilm formation under different cultivation conditions, we propose using some generalizing parameters. Thus, the intensity of biofilm formation was estimated according to the average sample area covered by biofilm $\left(\mathrm{B}_{\mathrm{av}}\right)$, its fluctuation amplitude $\left(\mathrm{B}_{\mathrm{amp}}\right)$ and indexes of maximum biofilm formation $\left(\mathrm{B}_{\max }\right)$. The data obtained was compared with the results of strain growth in optimal medium for cultivation (LB broth), characteristics of which were described earlier [12].

It can be noted, that under cultivation of $P$. aeruginosa UCM B-900, UCM B-1 and UCM B-12 in LB broth, microorganisms were characterized by considerable biofilm accumulation $\left(\mathrm{B}_{\mathrm{av}}\right.$, Table 1$)$ and intensive variation of biofilm forming indexes during the whole observation period $\left(\mathrm{B}_{\max }\right.$ and $\mathrm{B}_{\mathrm{amp}}$, Table 1).

At the same time, the titre of cells in planktonic form $\left(\mathrm{NPl}_{\mathrm{av}}\right.$, Table 2) maintained at high level, whereas bacteria quantity in biofilm composition was minimal $\left(\mathrm{NBp}_{\mathrm{av}}\right.$ and $\mathrm{NBp}_{\mathrm{sp}}$, Table 2$)$.

Table 1

The characteristics of Pseudomonas aeruginosa biofilm formation under different concentrations of carbon source in cultivation medium

\begin{tabular}{|c|c|c|c|c|c|}
\hline \multirow{3}{*}{$\begin{array}{l}\text { Indexes of biofilm } \\
\text { formation }\end{array}$} & \multirow{3}{*}{$\begin{array}{c}\text { Pseudomonas } \\
\text { aeruginosa } \text { strains }\end{array}$} & \multicolumn{4}{|c|}{ The cultivation medium used } \\
\hline & & \multirow{2}{*}{ LB broth* } & \multicolumn{3}{|c|}{ Kozer medium with glucose } \\
\hline & & & $0,1 \%$ & $5 \%$ & $20 \%$ \\
\hline \multirow{3}{*}{$\mathrm{B}_{\mathrm{av}}, \mathrm{mm}^{2}$} & UCM B-900 & 39,0 & 26,0 & 25,9 & 10,7 \\
\hline & UCM B-1 & 57,0 & 39,3 & 25,1 & 14,6 \\
\hline & UCM B-12 & 59,4 & 42,5 & 22,1 & 13,7 \\
\hline \multirow{3}{*}{$\mathrm{B}_{\max }, \mathrm{mm}^{2}$} & UCM B-900 & 153,6 & 54,1 & 37,3 & 18,8 \\
\hline & UCM B-1 & 172,6 & 61,5 & 35,7 & 23,0 \\
\hline & UCM B-12 & 105,6 & 74,8 & 37,3 & 25,6 \\
\hline \multirow{3}{*}{$\mathrm{B}_{\mathrm{amp}}, \mathrm{mm}^{2}$} & UCM B-900 & 150,1 & 40,5 & 20,4 & 13,0 \\
\hline & UCM B-1 & 169,2 & 34,7 & 20,3 & 15,9 \\
\hline & UCM B-12 & 74,1 & 53,4 & 23,9 & 21,8 \\
\hline
\end{tabular}

Annotations: * - results of previously obtained data [12] processing. $\mathrm{B}_{\mathrm{av}}$ - the average sample area covered by biofilm; $\mathrm{B}_{\max }$ - the index of maximal biofilm formation; $\mathrm{B}_{\text {amp }}$ - the fluctuation amplitude of sample area covered by biofilm. 


\section{Table 2}

\section{The main parameters of viable cell quantities of researched Pseudomo- nas aeruginosa strains under different concentration of carbon source in cultivation medium}

\begin{tabular}{|c|c|c|c|c|c|}
\hline \multirow{3}{*}{$\begin{array}{l}\text { The parameters of } \\
\text { viable cell quantities }\end{array}$} & \multirow{3}{*}{$\begin{array}{c}\text { Pseudomonas } \\
\text { aeruginosa } \\
\text { strains } \\
\end{array}$} & \multicolumn{4}{|c|}{ The cultivation medium used } \\
\hline & & \multirow{2}{*}{ LB broth* } & \multicolumn{3}{|c|}{ Kozer medium with glucose } \\
\hline & & & $0.1 \%$ & $5 \%$ & $20 \%$ \\
\hline \multirow{3}{*}{$\mathrm{NBp}_{\mathrm{av}}, \mathrm{CFU} \mathrm{ml^{-1 }}$} & UCM B-900 & $8.9 \times 10^{3}$ & $1.2 \times 10^{6}$ & $8.3 \times 10^{5}$ & $1.5 \times 10^{4}$ \\
\hline & UCM B-1 & $4.3 \times 10^{4}$ & $6.8 \times 10^{5}$ & $1.1 \times 10^{5}$ & $5.1 \times 10^{3}$ \\
\hline & UCM B-12 & $5.2 \times 10^{5}$ & $6.6 \times 10^{5}$ & $1.3 \times 10^{5}$ & $1.2 \times 10^{3}$ \\
\hline \multirow{3}{*}{ 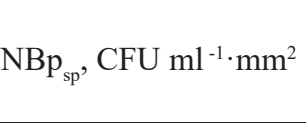 } & UCM B-900 & $2.3 \times 10^{2}$ & $4.5 \times 10^{4}$ & $3.2 \times 10^{4}$ & $1.4 \times 10^{3}$ \\
\hline & UCM B-1 & $7.5 \times 10^{2}$ & $1.7 \times 10^{4}$ & $4.4 \times 10^{3}$ & $3.5 \times 10^{2}$ \\
\hline & UCM B-12 & $8.8 \times 10^{3}$ & $1.6 \times 10^{4}$ & $5.9 \times 10^{3}$ & $9.0 \times 10^{1}$ \\
\hline \multirow{3}{*}{$\mathrm{NPl}_{\mathrm{av}}, \mathrm{CFU} \mathrm{ml}{ }^{-1}$} & UCM B-900 & $2.9 \times 10^{8}$ & $2.7 \times 10^{7}$ & $6.9 \times 10^{7}$ & $5.5 \times 10^{7}$ \\
\hline & UCM B-1 & $3.0 \times 10^{8}$ & $1.2 \times 10^{8}$ & $1.8 \times 10^{8}$ & $2.9 \times 10^{7}$ \\
\hline & UCM B-12 & $4.0 \times 10^{8}$ & $2.0 \times 10^{7}$ & $5.9 \times 10^{7}$ & $2.5 \times 10^{7}$ \\
\hline
\end{tabular}

Annotations: * - results of previously obtained data [12] processing. $\mathrm{NBp}_{\mathrm{av}}-$ the average quantity of viable cells in biofilm composition; $\mathrm{NBp}_{\mathrm{sp}}$ - the average exponent of specific quantity of viable cells in biofilm form in regard to sample area covered by biofilm; $\mathrm{NPl}_{\mathrm{av}}$ - the average quantity of viable cells in planktonic form.

The cultivation of $P$. aeruginosa under addition of glucose $-0.1 \%$ to $20 \%$ can be considered as the consequence of unfavourable environment conditions $[1,15]$. Under such conditions $B_{a v}$ indexes of UCM B-900, UCM B-1 and UCM B-12 strains went down in 2.4, 2.7 and 3.1 times, respectively (Table 1). Also, it was noticed the fluctuation decrease of biofilm formation features over time. This phenomenon for $P$. aeruginosa UCM B-1, UCM B-12 and UCM B-900 resulted in reduction of $\mathrm{B}_{\text {amp }}$ in 2.2, 2.4 and 3.1 times, and $\mathrm{B}_{\max }$ indexes - in 2.7, 2.9 and 2.9 times, respectively. Thus, increase of glucose concentration in the Kozer medium caused decrease of sample area covered by biofilm and stabilization of its accumulation dynamics.

While comparing average quantities of viable cells of $P$. aeruginosa UCM B-900, UCM B-1 and UCM B-12 in biofilm composition ( $\left.\mathrm{NBp}_{\mathrm{av}}\right)$ it was observed that under increased concentration glucose (from 0.1 to $20 \%$ ) these indexes decreased in 80, 133 and 550 times, respectively (Table 2). To examine if this phenomenon was related to reduction of sample area, the average exponent of specific quantity of viable cells in biofilm form $\left(\mathrm{NBp}_{\mathrm{sp}}\right)$ was assessed. This parameter, as compared with $\mathrm{NBp}_{\mathrm{av}}$, went down less intensively when the glucose concentration was increased. So, NBp sp $_{\text {sp }}$. aeruginosa UCM B-900, UCM B-1 and UCM B-12 fell by 32, 48 and 177 times, respectively. Therefore, reduced quantity of viable cells in biofilm composition was not only caused by a reduction of biofilm area, but also changed cultivation conditions. Thus, the rise of glucose concentration in Kozer medium from 0.1 to $20 \%$ caused the decrease of cell quantity in biofilm composition in 2.5-3.1 times, but did not result in their full elimination. In contrast to cells in biofilm composition, bacterium titre in planktonic form maintained on more stable level irrespective of cultivation conditions. So, under elevation of glucose concentration in terms of $0.1 \%$ to $20 \%$ the average quantity of viable cells of $P$. aeruginosa UCM B-900, UCM B-1 and UCM B-12 in planktonic form ( $\mathrm{NPl}_{\mathrm{av}}$ ) enlarged in 1.5, 2.5 and 3 times, respectively (Table 2). Further increase of glucose concentration in the medium to $20 \%$ resulted in 
decrease of $\mathrm{NPl}_{\mathrm{av}}$ indexes in 6.2, 1.3 and 2.4 times, respectively. Though, quantity of microorganisms in planktonic form under all used cultivation conditions didn't fall below $10^{7} \mathrm{CFU} \mathrm{ml}{ }^{-1}$. The results obtained proved, than increased carbon source concentrations in Kozer medium didn't considerably influence the bacterium titre in planktonic form.

Discussion. Revealed regularities enable to suppose, than $P$. aeruginosa in biofilm composition generate a pool of reserve cells, which can turn into planktonic form and provide stable quantity of free-swimming bacteria. Vlamakis H., Aguilar C., Losick R. et al. [16] hold the same opinion and declare that Bacillus subtilis cells can transfer from attached state to freeswimming form. Biofilm serves as a protective formation and is able to react to the influence of external factors by changing the intensity of cell accumulation. Optimal conditions of cultivation permit microorganisms to maintain high levels of titre of bacteria in planktonic form at a stable level. In this case lower quantity of cells is observed in composition of biofilm, allowing its substantial fluctuation. But, under unfavourable environmental conditions, such as the increase of carbon source concentration in medium, $P$. aeruginosa maintained the stable cell quantity in planktonic form too. In that case, the reduction of biofilm area was compensated by stabilization of it accumulation dynamics, that ensure the maintenance of viable microorganisms in biofilm form. Hence, it can be supposed that biofilm performs not only protective function, but also does as depository formation. It means that the purpose of the biofilm is the conservation of reserve cell pool in biofilm composition and the maintaining of stable cell quantity in planktonic form. Bacterial cells in biofilm form provide the survival of microbial population in certain econiche and bacterial cells in planktonic form carried out the search of new habitats [6]. As we showed, the leaving of bacteria from the biofilm is observed even under unfavourable conditions, which causes destruction of free-floating cells. The possible biological sense of this phenomenon is the preserve of bacterial population by cell transfer to a new econiche with better conditions. Exactly for this aim the biofilm supports the high titer of cells in planktonic form, realizing its depositary function. This supposition is confirmed by results, obtained previously at other cultivation conditions and after the treatment of biofilm by some antimicrobial substances [9]. The stimulation of active conversion of microorganisms from more protected existence form (biofilm) to less protected (planktonic) create facilities to increase the accessibility of bacteria to antibiotic effect. The peculiarities revealed can find practical application in medicine and veterinary science for liquidation or exhaustion of biofilm formation nidus in alive objects.

Thus, researched Pseudomonas aeruginosa strains kept ability to grow and form the biofilm under the presence of $0.1-20 \%$ glucose in Kozer medium. The microorganisms manifested their strain characteristics of biofilm formation, which under increased carbon source concentrations became less clear and gained more common features for all used cultures of microorganisms. The increase of glucose added caused reduction of the sample area covered by biofilm and quantity of microorganisms in its composition, stabilization of biofilm formation dynamics, but didn't influence on the bacterium titre in planktonic form. 


\title{
ДЕПОНУЮЧА ФУНКЦІЯ БІОПЛІВКИ \\ PSEUDOMONAS AERUGINOSA ПРИ РІЗНОМУ ВМІСТІ ДЖЕРЕЛА ВУГЛЕЦЮ В СЕРЕДОВИЩІ КУЛЬТИВУВАННЯ
}

\author{
О.І. Балко, Л.В. Авдєєва, О.Б. Балко
}

Інститут мікробіології і вірусології ім. Д.К. Заболотного НАН Украӥни, вул. Академіка Заболотного, 154, Київ, 03143, Україна

\section{Резюме}

Метою роботи було дослідження особливостей біоплівкоутворення Pseudomonas aeruginosa у середовищах із різним вмістом глюкози як єдиного джерела вуглецю та енергії. Методи. Культивування трьох штамів Pseudomonas aeruginosa проводили в стаціонарній системі на склі в середовищі Козера з 0,1\%, 5\% та 20\% глюкози. Вплив несприятливих умов на ріст мікроорганізмів оцінювали відповідно до змін інтенсивності біоплівкоутворення та кількості життєздатних клітин в планктонній формі та у складі біоплівки. Результати. Встановлено, що досліджувані культури зберігали здатність до росту та формування біоплівки за наявності в середовищі Козера від 0,1 до 20\% глюкози. За наявності в середовищі 0,1\% глюкози динаміка накопичення біоплівки характеризувалась штамовими особливостями. Проте при збільшенні вмісту джерела вуглецю до 20\% відмінності ставали менш вираженими, біоплівкоутворення набувало загальних для всіх використаних культур закономірностей. Підвищення концентрації внесеної глюкози спричиняло зменшення площі покриття зразків біоплівкою і кількості мікроорганізмів у їі складі, стабілізувало динаміку біоплівкоутворення, проте не впливало на титр бактерій у планктонній формі. Висновки. За впливу несприятливих факторів біоплівка Pseudomonas aeruginosa, окрім захисної функції, може виконувати роль депонуючого формування, яке забезпечує підтримання стабільної кількості клітин у планктонній формі.

Ключові слова: Pseudomonas aeruginosa, біоплівкоутворення, мікроорганізми у планктонній і біоплівковій формі, концентрація джерела вуглецю.

\section{ДЕПОНИРУЮЩАЯ ФУНКЦИЯ БИОПЛЕНКИ PSEUDOMONAS AERUGINOSA ПРИ РАЗЛИЧНОМ СОДЕРЖАНИИ ИСТОЧНИКА УГЛЕРОДА В СРЕДЕ КУЛЬТИВИРОВАНИЯ}

\author{
О.И. Балко, Л.В. Авдеева, А.Б. Балко \\ Институт микробиологии и вирусологии им. Д.К. Заболотного НАН Украины, \\ ул. Академика Заболотного, 154, Киев, 03143, Украина \\ Резюме \\ Целью работы было изучение особенностей биопленкообразования Pseudomonas \\ aeruginosa на средах, содержащих различное количество глюкозы в качестве \\ единственного источника углерода. Методы. Культивирование трех штаммов \\ Pseudomonas aeruginosa проводили в стационарной системе на стекле в среде Ко- \\ зера с $0,1 \%, 5 \%$ и $20 \%$ глюкозы. Влияние неблагоприятных условий на рост микро- \\ организмов оценивали согласно изменению интенсивности биопленкообразования \\ и количества жизнеспособных клеток в планктонной форме и в составе биопленки. \\ Результаты. Показано, что использованные культуры сохраняли способность к ро-
}


сту и формированию биопленки при наличии в среде Козера от 0,1 до 20\% глюкозы. При наличии в среде $0,1 \%$ глюкозы динамика накопления биопленки характеризовалась штаммовыми особенностями. Однако при повышении содержания источника углерода до 20\% отличия становились менее выраженными, биопленкообразование приобретало общие для всех использованных культур закономерности. Повышение концентрации внесенной глюкозы вызывало снижение площади покрытия образцов биопленкой и количества микроорганизмов в ее составе, стабилизировало динамику биопленкообразования, однако не влияло на титр бактерий в планктонной форме. Выводы. При влиянии неблагоприятных факторов биопленка Pseudomonas aeruginosa, кроме защитной функции, может исполнять роль депонирующего образования, которое обеспечивает поддержание стабильного количества клеток в планктонной форме.

Ключевые слова: Pseudomonas aeruginosa, биопленкообразование, микроорганизмы в планктонной и биопленочной форме, концентрация источника углерода.

1. Jahid IK, Lee NY, Kim A, Ha SD. Influence of glucose concentrations on biofilm formation, motility, exoprotease production, and quorum sensing in Aeromonas hydrophila. J Food Protect. 2013; 76:239-247.

2. Arweiler NB, Lenz R, Sculean A, Al-Ahmad A, Hellwig E, Auschill TM. Effect of food preservatives on in situ biofilm formation. Clin Oral Invest. 2008; 12:203-208.

3. Nikolaev YA, Plakunov VK Biofilm - "City of Microbes" or an analogue of multicellular organisms? Microbiology. 2007; 76:125-138.

4. Waite RD, Paccanaro A, Papakonstantinopoulou A, Hurst JM, Saqi M, Littler E, Curtis MA. Clustering of Pseudomonas aeruginosa transcriptomes from planktonic cultures, developing and mature biofilms reveals distinct expression profiles. BMC Genomics. 2006 Jun 26; 7:162. doi.org/10.1186/1471-2164-7-162.

5. Bester E, Wolfaardt G, Joubert L, Garny K, Saftic S. Planktonic-cell yield of a pseudomonad biofilm. Appl. Environ. Microb. 2005; 71:7792-7798.

6. López D, Vlamakis H, Kolter R. Biofilms. Cold Spring Harb Perspect Biol. 2010; 2(7):a000398. doi: 10.1101/cshperspect.a000398.

7. Lebeaux D, Chauhan A, Rendueles O, Beloin C. From in vitro to in vivo models of bacterial biofilm-related infections. Pathogens. 2013; 2:288-356.

8. Stoodley P, Sauer K, Davies DG, Costerton JW. Biofilms as complex differentiated communities. Annu Rev Microbiol. 2002; 56:187-209.

9. Balko OI, Balko AB, Avdeeva LV. [Biofilm forming capacity and bacteriocynogenity in Pseudomonas aeruginosa]. In: Mokienko AV, Pushkina VA, Gozhenko AI (ed) Biofilms of hospital ecosystems: current situation and modern approaches for its solving. Odessa: TOV VNP "Interservise"; 2014. p. 247-311. Russian.

10. Rasamiravaka T, Labtani Q, Duez P, El Jaziri M. The formation of biofilms by Pseudomonas aeruginosa: a review of the natural and synthetic compounds interfering with control mechanisms. Biomed Res Int. 2015; 2015:759348. doi: $10.1155 / 2015 / 759348$.

11. Smirnov VV, Kiprianova EA. [Bacteria of Pseudomonas genus]. Kiev: Naukova dumka; 1990. p.221-225. Russian.

12. Balko OI, Balko AB, Avdeeva LV. [Biofilm formation of Pseudomonas aeruginosa collection strains]. Mikrobiol Z. 2013; 75:50-56. Russian. 
13. Balko OI, Balko AB, Avdeeva LV. [The method of estimation of biofilm forming intensity in microorganisms]. Pat. 89509 UA, MPK C12Q 1/24 / Publ. 25.04.14, Bull. № 8. Ukrainian.

14. Balko OI, Balko AB, Avdeeva LV. [The method of quantitave estimation of viable microorganisms in biofilm composition]. Pat. 89508 UA, MPK C12Q 1/24 / Publ. 25.04.14, Bull. № 8. Ukrainian.

15. Huynh TT, McDougald D, Klebensberger J, Al Qarni B, Barraud N, Rice SA, Kjelleberg S, Schleheck D. Glucose starvation-induced dispersal of Pseudomonas aeruginosa biofilms is cAMP and energy dependent. PLoS ONE. 2012; 7(8):e42874. doi: 10.1371/ journal.pone.0042874.

16. Vlamakis H, Aguilar C, Losick R, Kolter R. Control of cell fate by the formation of an architecturally complex bacterial community. Gene Dev. 2008; 22:945-953.

Отримано 13.06.2018 